\title{
River: A Boon or a Bane
}

\section{K. Radha Madhavi ${ }^{1}$ and Harika Done ${ }^{2}$}

\author{
${ }^{1}$ Assistant Profess or of English, Sri Vasavi Engineering College, Tadepalligudem, Andhra Pradesh, India. \\ ${ }^{2}$ Senior Assistant Profess or of Environmental Studies, Sri Vasavi Engineering College, Tadepalligudem, Andhra Pradesh, India. \\ Jahnavi.nanduri@gmail.com
}

\begin{abstract}
Rivers are the back bone of human civilization. History says that various prominent civilizations like the Nile River valley, the Indus River valley, the Yellow River valley etc, formed around rivers. That is why every culture, civilization, folk and literature has a strong bonding to the rivers. In India, rivers are venerated as Goddesses. Indians worship River as a mother. Like a mother, each river has a pleasant (saumya) and an unpleasant (urga) forms. Considerably good amount of literature is available related to rivers explaining its beauty but only hand full of poets have seen the other side of the coin where it is devastating many lives. The objective of this paper is to focus on the two different versions of the river in literature.
\end{abstract}

Keywords-River, Boon, Bane.

\section{INTRODUCTION}

Rivers are an integral part of Indian culture, civilization, religion and literature. Rivers served as rich source of inspiration to writers of every genre. Right from the Vedas and epics like the Ramayana and the Mahabharata, Indian literature has found ample references to rivers. Rivers were not only the medium to improve the life but also the means to maintain the heavenly life. This coexistence and bonding have been expressed in very emotional, realistic, strong and artistic manner during all the stages of literature. It is hard to find classics devoid of river motifs in Indian English Literature also. It is very important to keep a good bonding else it can show its fierce face and destroy everything. Floods are an example of the fiery face of rivers. It takes away a large number of lives with it.

Writers from every part of India have created abundant literature centered on rivers. The tradition of praise of rivers continues but many poets have also visualized the rivers differently as destructive force. This paper discusses how poets like A. K. Ramanujanwere sensitive to the havoc caused by rivers in his poem 'A River'. The poet raises the question of an artistic commitment to the society. Whereas poets like A. N. Dwivedi sings both the glorious and ferocious nature of rivers.

\section{A.K.Ramanujan's 'A River':}

Attipat Krishnaswami Ramanujan was a poet, translator and scholar of Southern Indian Literature. He was born in Mysore, India and spent the second half of his life in the United States. Because of his cross cultural ties he says he was "the hyphen in Indo- American".

R. Parthasarathy in his introductory note on Ramanujan in 'Ten Twentieth Century Indian Poets', reads 'A River' as a poem that exposes the callousness of the old and the new poets to the human sufferings. He concludes that both the groups of the poets are indifferent to human sorrow and suffering.

The poem is about the river, Vaigai which flows through Madurai city. Madurai is the nerve-centre of Tamil culture and in his poem 'A River' Ramanujan writes thus

"In Madurai,

City of temples and poets

Who sang of cities and temples."

The poet presents two alternative perceptions of river: a vivid picture of the river in the summer season and the river in its full flow when the floods arrive with devastating fury. The river which is the symbol of life and fertility becomes a destructive force. Both old and new poets write about the beauty of river in full flood completely ignoring the wreckage and human tragedy caused by rivers.

Ramanujan in his much applauded poem 'A River' voices his concern over the deteriorating state of people in India. The traditional symbol of river as the nourisher and preserver is turned upside down when it is dried in summer and gives a picture of malnourished and uncared humanity during floods.

----every summer

A river dries to trickle

In the sand....

The poet gives a vivid picture of the river during summer. The river is almost barren and arid. Only a very thin stream of water flows revealing the sand ribs on the bed of the river. The stones that lie on the bed could be seen. Water cannot pass through the water gates because of the piles of straw and woman's hair that obstruct its flow. The 
dry stones are all like the sleeping crocodiles. The dry stones look like 'shaven buffaloes'. Such scenes are not described by the poets. 'Sleeping crocodile', 'shaven buffaloes' symbolize the degeneration of human nature. The impression of the stones in the rivers has been successfully conveyed thus-

"---- the wet stones glistening

Like sleepy crocodiles the dry ones

shaven water buffaloes -----“"

Ramanujan records the response of the people to the flood. During the rainy season when the floods hit, the people observe it anxiously. They see the stones of bathing place being submerged one by one. The village houses, a pregnant woman and a couple of cows are washed away.

“---- it carried off the village houses, one pregnant woman and a couple of cows named Gopi and Brinda----_“

The image of the pregnant woman is significant for it involves two generations, the present and the future .Again there is a mention of names of cows but there is no mention of the names of the pregnant woman which reflects the callous nature of human beings.

Ramanujan satirizes both the old and new poets who celebrate the beauty of rivers. Even the new poets blindly followed the old poets and they did not notice the pain and suffering of the people. Ramanujan writes:

"The new poets, still quoted

The old poets, but no one spoke

In verse of the pregnant woman----“"

Ramanujan differs from the poets as he sees no richness, he sees only death and sorrow in the symbolism of un born twins and cows. The old and new poets deemed it enough to versify and exalt the river only when it is flooded once a year.

\section{"The river has water enough to be poetic about only once a year'.}

While the poets sang of a river as a creative force giving birth to new life, the paradox of the pregnant woman who drowned with twins in her eludes them. The poet has ironically exposed the heartless attitude of both the old and new poets.

\section{A.N. Dwivedi's 'The Grandeur of the Ganges':}

Amar NathDwivedi is a well-known critic and poet in English. He is a senior professor of English who retired from the University of Allahabad. Now Dwivedi is engaged in his multiple writing projects.
A.N.Dwivedi's poem 'The Grandeur of the Ganges' refers to the grandeur of the river not only to the religious people but also to the boats men, fisherman and farmers. The second stanza draws on the myth associated with the river Ganges.

According to Hindu Mythology, there was a powerful king named Sagar. He performed Ashawamedhayaga to declare his supremacy. The king of HeavenIndra grew jealous of king,Sagar and decided to steal the horse. Indra abducted the horse and tied the horse in the ashram of sage Kapil, who was meditating from so many years. King Sagar ordered his 60,000 sons to search for the horse. After a long search they found the horse in the ashram and began assaulting the sage thinking that he has stolen the horse. The sage opened his eyes and at one glance all the 60,000 sons turned to ashes. When king Sagar pleaded the sage, the sage told king Sagar that only way for the souls of dead sons to rise to ascension in heaven is to wash their bodies with sacred Ganges. King Bhagirath, grandson of King Sagar performed penance for one thousand years to please Brahma. The poet very beautifully explains the myth associated with the river Ganges in the following lines.

\section{'The herculean efforts of the illustrious Bhagirath $\mathrm{n}$ her consent to come down'}

In the next few lines the poet explains howBrahma was pleased and agreed to send the Ganges down to the earth. Brahma advices Bhagirath to propitiate Lord Siva, so that Siva would agree to let the Ganges fall on his head, since its force would otherwise destroy the earth.

' her proud descent from the heavens

$$
\begin{aligned}
& \text { Sustained by Lord Siva } \\
& \text { in whose dark tresses } \\
& \text { she lost her track; } \\
& \text { her release from there } \\
& \text { on the devout prayers } \\
& \text { of anxious men n gods; }
\end{aligned}
$$

After one year of penance Lord Siva assured Bhagirath that he would hold Ganga's fall on his matted locks. Lord Siva let Ganges free after crushing her vanity.

' her impetuous sweep forward
over the snowy peaks
of the high Himalayas
thus the gurgling gorges
$\mathrm{n}$ deep green forests
to the cursed site
where lay the ashes n bones
of sixty thousand sons of Sagar.

Then the poet says ; 
'the great river is enveloped

In multiple mythsand legends.

The third stanza portrays the grandeur of the river in the month of magh when a new township springs up at the sangam where millions of men and women came trooping along, chanting glory of the mother to have a holly dip. The poet is not swept of his feet by his religious current flowing in the city. He sees how religious and irreligious, real devotes and imposters, pious and profane are mixed together in the confluence festival in the city of Allahabad.

'All kinds of business thrives here

in a sacrosanct atmosphere

imposters n thieves not excludes"

The last stanza takes up the grandeur of violence of the river in spate, destroying all kinds of life "as though power-drunk", she works as a good cleaner of dirt, refuge and garbage. Despite the havoc caused by the river in its rudra form is seen by the poet as a boon to all living creatures.

$$
\begin{aligned}
& \text { The rarefied air is a gift } \\
& \text { of the swollen Ganges }
\end{aligned}
$$

to living creatures of all kinds.

It is clear that in Dwivedi's poem myth, folk lore and ritual mingle with the image of chaos, destruction and violence which questions the role and existence of the river. There are enough suggestion that modern civilization is trying to undo the efforts of Bhagirath by chocking the rivers flow and inviting death without knowing it.

\section{CONCLUSION}

The river is perhaps one of the richest topics in literature and arts. From the ancient times, the river has been seen as a very meaningful image: change, purification, enlightenment, separation, peace. The river is also a beautiful image of adventures and unending joys but, at the same time, it may be an image of melancholy and agony. Literature is the best tool to create awareness to the readers in presenting not only the beauty of the river but also the pathetic angle.

\section{REFERENCES}

[1] https://www.hinduwebsite.com/symbolis m/.../river.asp

[2] https://www.africanwater.org/religion.htm

[3] https://ardhendude.blogspot.com/.../a-river-by-akrama...

[4] Ramanujan, A.K. "A River" The Striders. Ed. Ramanujan. London: OUP, 1966. np. Print.
[5] Indian English Poetry and Fiction: A Critical Evaluation edited by N. Raj Gopal, Suman Sachar

[6] https://beamingnotes.com > ICSE Poems 